\title{
Electrical Impulses
}

\author{
Marina Vesic \\ University of Music and Performing Arts \\ in Vienna \\ University of Music and Performing Arts \\ in Belgrade \\ SRB - Serbia \\ marinablackmarine@gmail.com
}

\author{
Diogo Lopes \\ Faculty of Engineering \\ University of Porto \\ High School of Arts and Design \\ of Caldas da Rainha \\ PT - Portugal \\ organon.contemporaneous@gmail.com
}

\section{INTRODUCTION}

The project comprises of a real-time performance creating a mixture between the different processes, where it includes both contemporary classical and electro-acoustic music. It is focused on a piano and clarinet performance and the fusion between micromontage, concrete sounds and live-electronics. The project explores an area of research by observing the sound matter and what kind of sound is operating. It may be presented with the assistance of electronic technology involving instrumental performance, or, even a human voice. This resulting conditioning becomes the continuous representation of time and space.

\section{CONCEPTS AND DEVELOPMENT}

Micromontage, live-electronics and instrumental performance, above all else, create different environments between them. In the instrumental performance, the clarinet explores the limits of sound representation and possibilities within the instrument itself, amplifying it with live electronics. The piano's Instrumental performance creates in itself, different impulses that can balance between the demarcation of continuous and strong rhythmic sounds and a perception that changes itself in the contextualization of the representation of space.

\subsection{Micromontage}

This was utilized by IRIN Micromontage's software developed in MaxMSP by Portuguese composer Carlos Caires (2004). Micromontage is a composition technique based on the organization of time and space of events utilizing different types of sound objects, similar to the way that was followed by the French school, which can be observed in micro, meso and macro-scale, permitting the understanding of sounds as a whole and as one construction in musical terms. These terms were

the centre of the research and development of the tool used for this composition.

Concepts like cell, figure, counterpoint, polyphony, layers, background/foreground, variation/repetition, and so on, are permanently involved in the process of composing, as much in instrumental music as in electroacoustic music ...'

Horacio Vaggione (2002), the principle author of this, chooses the philosophic environment, from Gaston Bachelard, and concept of 'racionalisme de l'energie' to designate and characterise the knowledge of the micro-temporal pluralism, and also to built your understanding of the concept of 'Décorrelation'.

To make it easier to understand the concept of 'decorrelation', it is something that can defined as the 'making of a reply and then putting them on different channels', 'building polyphony' and 'working in the field of micro-time'. This is the central part of the creation and which can determine the distribution of the energy rationalism, in Bachelard's perspective.

One of concepts that are important to keep in mind are those of 'interaction', that have implications on the fact that, if utilizing this technique with sound, it is not in real-time. This has to do with the composers having an effect on the interactions of one tune with sound, leading to the single position of the listener.

'... Le compositeur en tant qu'anditeur constitue le corrélate du compositeur en tant que producteur: afin de produire de la musique, un acte d'audition est nécessaire, quíl s'agisse de l'audition 'intérieure' (la situation décriture silencieuse) de la composition instrumentale pure ou de l'audition 'concréte' de la composition musicale électroacoustique. Ces situation impliquent des variants (il en existe plusieurs autres) d'une boucle 
de feedback action/perception, qui peut être define comme une instance de validation popre aux processus musicaux ...'

This can be translated as '... The composer as anditeur is the correlation of the composer as a producer: to produce music, an act of hearing is necessary, quil's hearing 'domestic' (the silent writing situation) instrumental pure composition or the 'concrete' hearing ' of electro-acoustic music composition. These situations involve variants (there are several others) of a feedback action/perception loop, which can be defined as an instance of validation in one's own musical processes...'

To comprehend this point of convergence is to understand the process of micro-montage's construction from a philosophical perspective. Whereas in a embracing perspective the type of registration takes a better control of sound objects represented in different multi-dimensions and leads the composer to take the role of listener too.

\subsection{Clarinet Performance}

This uses a patch developed in MaxMSP for sound creation using an instrumental performance.

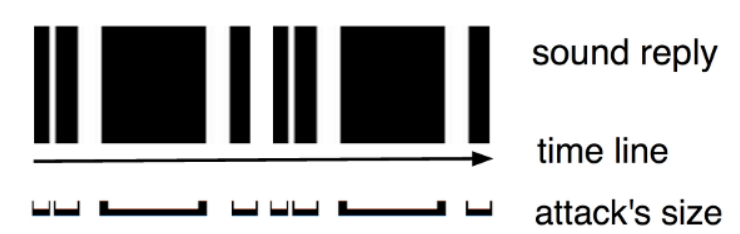

Figure 1: Diagram about patch developed in MaxMSP

By representing what is happening with the performance sound of the clarinet, this clarifies and helps us to understand its importance. This is comprehended in real-time, though a reactive application that detects the attacks and will measure the distance between them, modifying the size of sampling with each attack, and triggering with each attack, a new sound reply that will vary according with attack's size, along the timeline.

In that space-time is the key of compositional comprehension, and in that the sound it is explored as limit of representation. Based on one area of research that I have developed, the sound is explored as design's prolongation. This is based in the work of artist Alberto Carneiro (1995), and has been the reference point in studying the exploration of design as architecture.

\subsection{Electronics}

In this field, I am using my samples created in MaxMSP and working in Ableton Live. Using MPK25, I create live music in the moment that it inspires me. My sense of music gives different impulses so that working, together with the clarinet consists of one new single field.

\subsection{Piano Performance}

Playing live together with Ableton live and mixing it together gives one new impulses. As piano is another media, both with harmonies and rhythm together with clarinet give more intense impulses.

\section{REFERENCES}

Caires, C. (2004) IRIN: Micromontage in Graphical Sound Editing and Mixing Tool. Centre de Recherche Informatique et Création Musicale (CICM), Université de Paris VIII, France. http://hdl.handle.net/2027/spo.bbp2372.2004.045 (retrieved 25 June 2015).

Solomos, M. (2007) Espaces Composables: Une Introduction à la pensée musico-théorique d'Horacio Vaggione. L'Harmattan, pp. 29-68. https://halshs.archives-ouvertes.fr/hal-00770211 (retrieved 25 June 2015).

Vaggione, H. (2002) Décorrelation microtemporelle morphologies et figurations spatiales. Centre de Recherche Informatique et Création Musicale (CICM), Université Paris VIII, France. http://jim.afimasso.org/jim2002/articles/L27 Vaggione.pdf (retrieved 25 June 2015).

Carneiro, A. (1995) Campo sujeito e representação no ensino e na prática do desenho/projecto. FAUP. 